\title{
Retrospective vs. Prospective Corrective Feedback Impacts on Developing EFL Learners' Writing Ability and Learner Autonomy
}

\author{
Gholam-Reza Abbasian \\ Imam Ali University \& IAU, South Tehran Branch, Tehran, Iran \\ Poopak Bahmani \\ Department of English, South Tehran Branch, Islamic Azad University, Tehran, Iran
}

\begin{abstract}
Giving corrective feedback has always been a salient feature of the teaching profession including the teachers of EFL writing. The relationship between learner and different types of the feedback he/she receives can be central to fostering autonomy, too. Thus this study aims to compare the Iranian EFL learners' writing ability and their autonomy when receiving two different corrective feedback in writing: Retrospective vs. prospective corrective feedback. For this purpose, forty two Iranian intermediate-level EFL learners aged 1619 years old were chosen. During ten treatment sessions writings of retrospective group were corrected, lists of frequent errors were then presented to the learners. The frequent errors identified from the writing of retrospective group were highlighted for the prospective group prior to their writings. Their performance measured by a per-test and post-test revealed that the participants led by the prospective corrective feedback outperformed the retrospective group, but showed no significant promotion in their autonomy in learning.
\end{abstract}

Index Terms-corrective feedback, learner autonomy, prospective corrective feedback, retrospective corrective feedback

\section{INTRODUCTION}

Teaching writing has been regarded as one of the most complex and difficult tasks for English language learners and teachers. It requires teachers to spend a lot of time on reading and assessing students` writing during the post-writing stage, while there may still be no significant improvement in student`s writing skills. Instead of focusing on how to construct a perfect piece of writing, teachers start to believe that corrective feedback is more useful for helping our students to monitor their own mistakes and become independent writers. As Swain (1995) argued about the importance of drawing on second language learners productive skill for teachers because producing output, not only promotes noticing of linguistic features, but combined with feedback, it also pushes learners`awareness towards the gaps and problem in their interlanguage (IL). Moreover, the character of writing provides learners with more time and opportunity to compare the IL output to the target language (TL) feedback than oral production does. In writing, learners do have time to compare their output with the provided feedback, and as a result are more likely to notice a gap in their IL. Adams (2003), therefore, claims that written production and feedback are of special importance for second language acquisition. A crucial question is what this feedback should like. Corrective feedback is the common type of instructional mechanism used in EFL classroom settings, whereby teacher puts marks on students' errors. Nevertheless, it is controversial if type of feedback contributes L2 learners to enhance their writing ability in general and its accuracy in particular (Kepner, 1991; Truscott, 1999; Ferris, 1999). To further explore of its positive effects in language learning, recent researches have focused on types of feedback. Mac Grath(2002), stated two styles of giving feedback in learner involvement: (1) retrospective feedback, whereby the teacher exploits learners language in the form of lists of frequent errors, which are normally presented back to them after the activity done(e.g. a piece of writing), and used as a stimulus to self- correction or general awareness raising. (2) prospective feedback whereby the errors generated can be useful in predicting any prospective and possible errors of future classes on the same or similar activity.

\section{Corrective feedback}

Corrective feedback refers to teacher`s input indicating to the learners that their use of the target language is grammatically inaccurate or defective in communication (Lightbown \& Spada, 1999). It incorporates the procedures of providing treatment to an error, eliciting a revised student response and supplying "the true correction" (Chaudron, 1988). It enables learners to notice the gap between their interlanguage forms and the target language forms (Panova \& Lyster, 2002), makes further hypothesis and prevents errors from further production. Comprising feedback on language form and ranging from comments on the use of vocabulary items to correction over grammar and mechanical errors, corrective feedback can be rendered either explicitly or implicitly or it can be either coded or uncoded while being applied comprehensively o respectively. 
Although so many studies have been carried out as to the role of corrective feedback during the recent years, there are still so many questions have been left intact. This what as Lyster and Mori's (2006) Counterbalance Hypothesis raises "How should errors be corrected?" on the ground that educational and discourse contexts of L2 classroom setting imposes pertinent error correction strategy or type on teachers. However, Truscott (1996, 1999, 2007) opposes error correction, arguing that all varieties of correcting L2 learners' error in writing are not only ineffective but also debilitative so they should be quitted. Furthermore, he reiterated that in spite of the learners' tendency to grammar correction, teachers should be reluctant in meeting their desires. Contrary to Truscott, Ferris (1999) argued that grammar correction entails certain positive effects. In spite of extensive research studies some researchers (Kepner, 1991; Chandler, 2003; Bitchener, 2008) hold that it is too immature to talk of a conclusive answer to the problem of the effectiveness of error correction is effective in developing the accuracy feature of L2 writing, which is a rationale behind teachers' responsibility to appreciate the students' willingness to receive feedback for their errors in writing skill.

\section{Learner Autonomy}

Trends of educational research in general and language teaching particularly focuses more on an instruction which empowers learner thereby s/he can be an autonomous learner. If ,then, can be safely claimed that any measures taken by a language teacher, including giving feedback or correcting errors, showed learner autonomy. In this respect, Little (1991) held that the concepts of autonomous learning has gained momentum recently, such that it is appearing a 'buzzword' in L2 learning context. Learner autonomy has been so momentum that Wenden (1998) reiterates that it is one of the spin-offs of more communicatively oriented language learning and teaching processes. However, it is too a broad agreement to convince oneself that autonomous learners appreciate the aim of their own learning program, clearly welcome responsibility for their learning, exchange in the context of learning objectives, take initiatives in the processes of planning for and implementing learning activities, and constantly monitor and assess its effectiveness (Holec 1981, Little 1991). Benson (2001) believes that almost all research studies in the area of autonomy is fundamentally based on three hypotheses including : the nature of autonomy and its components, the possibility of escalating autonomy among learners, and the efficiency of certain approaches to enhance it.

Most writing teachers consider feedback, in general, a boring and unrewarding task. Teachers have to adopt feedback methods that encourage students to reconsider, revise, and rework their drafts to make any type of feedback an effective tool in the writing classroom. Majority of the research min the area of correcting writing errors show that learners who receive error feedback from their teachers enhance in their accuracy in the course of time. Contrary to this, it is still blurred the extent to which explicit feedback on error can helpful to their autonomy. The problem is which types of feedback are more effective to develop writing ability and fostering the learners`autonomy in learning. More specific, the problem is first, which type of feedback can be more effective in developing not only the writing ability but also learning autonomy in writing skill. As the instructional setting and discourse context of the classroom will dictate the best error correction type for teachers to use, error correction is an area where research can inform and improve practice. Teacher educators are not sure about the type of strategies effective in this arena. They are of the idea that the process of correcting errors is something complex in the light of a number of competing factors, so they have been reluctant to prescribe the strategies that teachers should use. Furthermore, according to Benson (2001) "in the field of foreign language teaching and learning as the theory and practice of language teaching enters a new century, the importance of helping students become more autonomous in their learning has become one of the more prominent themes (p. 1). He also states "learner autonomy achieved through learner training and strategies, which have been described as methods of developing the skills that learner need for autonomy" (p. 11). An autonomous learner is responsible for making decisions, implementing them and assessing the outcome. To address this issue this study has been investigating whether certain types of corrective feedback namely prospective corrective feedback and retrospective one help L2 students improve the accuracy of their writing and to increase their autonomy. There has been little research done, at least in Iran, to examine and promote this wide range of writing feedback styles and their impacts on EFL learners writing ability and to foster learner`s autonomy

\section{Methodology}

\section{Participants}

Forty two Iranian female and male intermediate-level Iranian EFL learners aged 16-19 years old took part in this study. At the time of data collection, most of them had been learning English as a Foreign Language (EFL) for one year. Two classes each including 21 EFL learners identified as experimental groups, both of them received writing instructions, while the other through retrospective feedback while ,the other received prospective feedback based on the errors of other group.

\section{Materials}

In order to run this study the researchers used three series of materials including:

1. The Preliminary English Test (PET) was employed in two stages both prior to the treatment and after it. The test was administered to the participating groups enjoying same level of language proficiency.

2. Autonomy Inventory: In order to investigate the learner autonomy of the subjects, the researcher applied the Inventory designed by Zhang and Li (2004, p.23). 
3. Writing sub-test of the PET as a measure of writing ability .It was used both prior to and after the experiment; the pre-test and post- test, respectively.

4. Instructional Materials: In addition to the tests, the researcher used some instructional materials for experimental group. The course books used in this study were Paragraph Development: A Guide for Students of English (1990) by Arnaudet \& Barret. The participants were taught the materials during the course.

\section{Procedure}

The purpose of the present study was to investigate the effect of two types of feedback on the Iranian EFL learners' writing ability and their autonomy.

At the first stage of this research, language proficiency test (PET), and autonomy inventory were administered to both groups. PET was employed to homogenize the participants regarding their proficiency in English. Those participants who scored one standard deviation above and below the mean were included in this study. Both experimental groups received conventional writing instruction. After 10 educational sessions, the PET and autonomy inventory were administered to both groups again.

\section{RESUltS AND DATA ANALYSIS}

\section{Reliability Estimation of the PET}

The reliability of the Preliminary English Test (PET) as displayed in table 1 below was computed through Cronbach's Alpha reliability formula that shows .889 as an acceptable index.

TABLE 1.

RELIABILITY INDEX OF THE PET SCORES

\begin{tabular}{|c|l|l|}
\hline Test & Cronbach's Alpha & N of Items \\
\hline PET & .889 & 21 \\
\hline
\end{tabular}

\section{Homogeneity Measures}

Prior to any decision on the statistical approach, the data was checked in terms of homogeneity and normality assumptions. The descriptive statistics for the two groups are displayed in following tables 2 and 3. According to table 2, the values of skewness and kurtosis are within the range of \pm .96 .Then, the data enjoyed normal distribution which is allowed to follow parametric approach and run t-tests.

TABLE 2

THE DESCRIPTIVE STATISTICS OF THE PET SCORES BY RETROSPECTIVE AND PROSPECTIVE GROUPS

\begin{tabular}{|l|l|l|l|l|l|l|l|}
\hline & $\mathrm{N}$ & Mean & Std. Deviation & Skewness & \multicolumn{2}{l|}{ Kurtosis } \\
\cline { 2 - 8 } & Statistic & Statistic & Statistic & Statistic & Std. Error & Statistic & Std. Error \\
\hline PETHomogtestRetro & 21 & 60.7143 & 4.61674 & -.687 & .501 & -.537 & .972 \\
\hline PETHomogtestPros & 21 & 60.6190 & 4.59865 & -.752 & .501 & -.071 & .972 \\
\hline Valid N (listwise) & 21 & & & & & & \\
\hline
\end{tabular}

Table 3 shows the results of the independent t-test and the Leven's test for equality of variances.

TABLE 3.

THE LEVENE'S AND INDEPENDENT T-TEST OF THE PET SCORES BY RETROSPECTIVE AND PROSPECTIVE GROUPS USED AS THE HOMOGENEITY TEST

\begin{tabular}{|c|c|c|c|c|c|c|c|c|}
\hline & \multicolumn{2}{|c|}{$\begin{array}{l}\text { Levene's Test for Equality of } \\
\text { Variances }\end{array}$} & \multicolumn{5}{|c|}{ t-test for Equality of Means } \\
\hline & & $\mathrm{F}$ & Sig. & $\mathrm{t}$ & df & $\begin{array}{l}\text { Sig. (2- } \\
\text { tailed) }\end{array}$ & $\begin{array}{l}\text { Mean } \\
\text { Difference }\end{array}$ & $\begin{array}{l}\text { Std. Error } \\
\text { Difference }\end{array}$ \\
\hline \multirow{2}{*}{$\begin{array}{l}\text { Homoge-niety } \\
\text { Test }\end{array}$} & Equal variances assumed & .077 & .783 & .067 & 40 & .947 & .09524 & 1.42197 \\
\hline & Equal variances not assumed & & & .067 & 39.999 & .947 & .09524 & 1.42197 \\
\hline
\end{tabular}

The mean scores for the retrospective and prospective groups were 60.71 and 60.61 , respectively. To run a t-test required observation of two assumptions of normality of the scores and homogeneity of variances. Tables 2 and 3 illustrate that the groups enjoyed normally as the ratios of skewness statistic over standard error was within the range of plus and minus 1.96 .

Moreover, the groups proved to be homogenous as well. As shown in Table 3, the Levene F of .077 had a probability of .783. Given the fact that the probability associated with the Levene F is higher than the significance level of .05, it then could be claimed that that variances are homogeneous on the post-test of writing section. Furthermore, since the probability of $\mathrm{t}(.067)$ had the sig (.947) that is higher than the significance level of .05 , it could be concluded that the two groups were homogeneous regarding their language proficiency. Therefore, no statistically significant difference is seen between the mean scores of the participants on the PET, signifying that they were homogenous in terms of their general English language proficiency before the treatments.

Data Analysis for the Writing Section of the PET Used as a Pretest

Table 4 below shows the Levene's test for equality of variances and the result of the independent t-test. 
TABLE 4.

INDEPENDENT T-TEST OF THE WRITING SECTION OF THE PET SCORES PRIOR TO THE TREATMENT

\begin{tabular}{|c|c|c|c|c|c|c|c|c|}
\hline & \multicolumn{2}{|c|}{$\begin{array}{l}\text { Levene's Test for Equality of } \\
\text { Variances }\end{array}$} & \multicolumn{5}{|c|}{ t-test for Equality of Means } \\
\hline & & $\mathrm{F}$ & Sig. & $\mathrm{t}$ & df & Sig. (2-tailed) & $\begin{array}{l}\text { Mean } \\
\text { Difference }\end{array}$ & $\begin{array}{l}\text { Std. Error } \\
\text { Difference }\end{array}$ \\
\hline Writing & Equal variances assumed & .107 & .746 & .871 & 40 & .389 & 2.38095 & 2.73447 \\
\hline Homogtest & Equal variances not assumed & & & .871 & 39.909 & .389 & 2.38095 & 2.73447 \\
\hline
\end{tabular}

The statstics reveal that the mean scores for both groups (i.e., retrospective \& prospective) were 56.19 and 53.80 , respectively. Obviously, then there was not any significant difference between them in terms of the mean scores on the writing section because the probability of $t \mathbf{( . 8 7 1 )}$ had the sig (.389) that is higher than the significance level of .05.Therefore, it could be concluded that the two groups were homogenous in terms of their writing ability prior to the administration of any treatment. Below are the pie charts for the writing section of the PET test for retrospective and prospective groups.

\section{Addressing the First Research Question}

In a bid to address the first research question "Does retrospective corrective feedback have any significant effect on developing EFL learners writing ability?", paired t-test was conducted to compare the mean scores of the participants on the pretest and posttest of the retrospective group on the writing in order to investigate the effect of retrospective feedback on the improvement of the writing ability of retrospective group. Table 5 shows the results of the paired t-test for the PET scores gained by the retrospective group

TABLE 5.

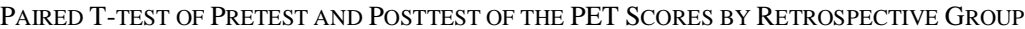

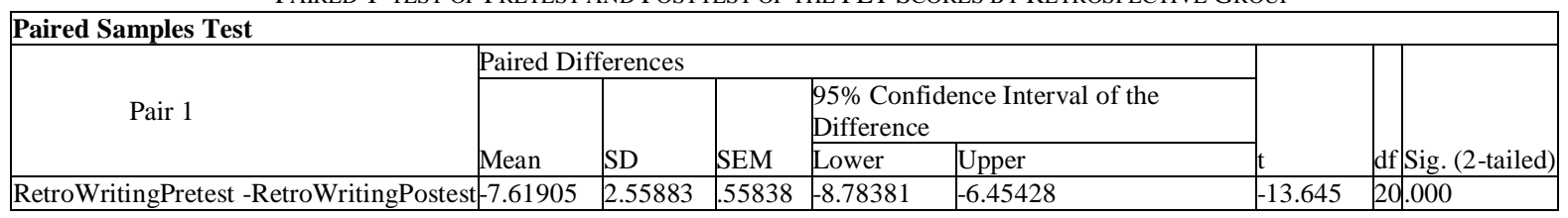

It is shown in table 5 that the mean scores for the pretest and posttest of retrospective groups were 56.19 and 63.80 , respectively. As it can be seen, the probability of t (13.64) had the sig (.000) that is lower than the significance level of .05. Therefore, it could be concluded that the mean scores of the two groups were significantly different. Consequently, our hypothesis that "retrospective error focused feedback doesn't have any significant effects on developing EFL learners writing ability" is rejected.

\section{Addressing the Second Research Question}

The second research question entitled "Does prospective corrective feedback have any significant effect on developing EFL learners writing ability?" was addressed via a paired t-test to compare the mean scores of the participants on the pretest and posttest of retrospective group on the writing in order to investigate the effect of retrospective feedback on the improvement of the writing ability of retrospective group.

The mean scores for the pretest and posttest of prospective group were 53.80 and 77.14, respectively, so the prospective group performed better in posttest than pretest .Similar to the first research question, paired t-test was run to test the second null hypothesis. Table 6 shows the results of the paired t-test for the PET score gained by the prospective group.

TABLE 6.

PAIRED T-TEST OF PRETEST AND POSTTEST OF THE PET SCORES BY RETROSPECTIVE GROUP

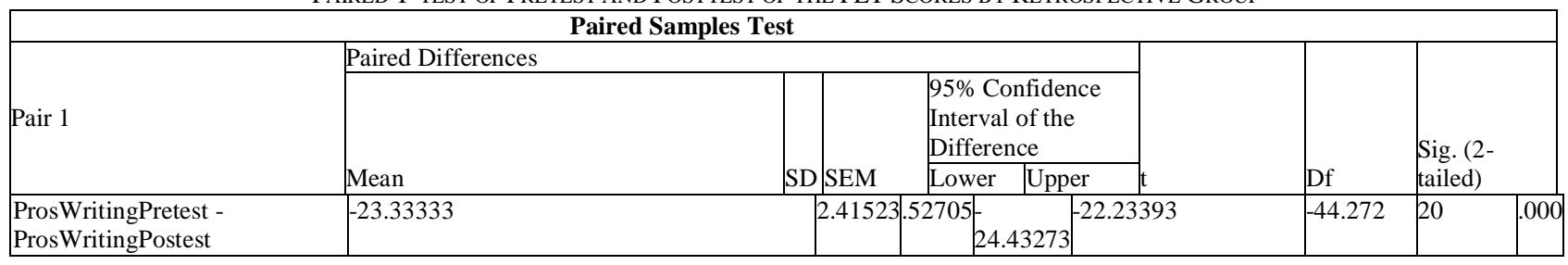

As it can be seen, the probability of $\mathrm{t}$ (44.27) had the sig (.000) that is lower than the significance level of .05, therefore, it could be concluded that there was a significant difference between the mean scores of the pretest and posttest groups. Consequently, our assumption that "Prospective error focused feedback doesn't have any significant effects on developing EFL learners writing ability." is rejected.

\section{Investigation of the Third Research Question}

In order to answer the third research question "Does retrospective corrective feedback lead to more achievements in EFL learners writing ability than prospective corrective feedback does?", an independent t-test was also run to compare the mean scores of posttest of writing in both groups in order to investigate the achievement of retrospective corrective feedback than prospective corrective feedback in writing ability. 
The mean scores for the posttest of retrospective and prospective groups were 63.80 and 77.14, respectively, so the prospective group outperformed the retrospective group in posttest of writing. Table 7 shows the results of the Independent $t$-test of the posttests of writing for both groups, retrospective and prospective.

TABLE 7.

INDEPENDENT T-TEST OF THE POSTTESTS OF WRITING FOR BOTH GROUPS

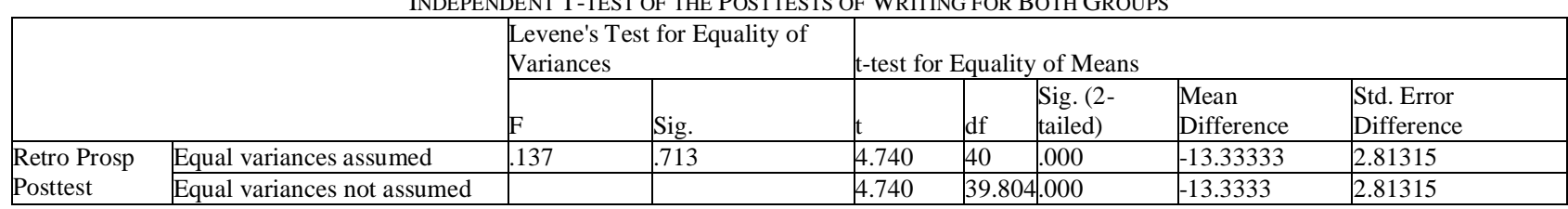

As it can be seen, the probability of $t$ (4.74) had the sig (.000) that is lower than the significance level of .05. Therefore, it could be concluded that there was a significant difference between the mean scores of posttest for the two groups. Consequently, our assumption that "retrospective corrective feedback" does not lead to more achievements in EFL learners writing ability than prospective corrective feedback is accepted meaning that the prospective group performed better and achieved more regarding the treatment and feedback.

\section{Investigation of the Fourth Research Question}

In an answer to the fourth research question "Does retrospective corrective feedback lead to more autonomy in EFL learners than prospective corrective feedback does?", an independent t-test was conducted explore any differences on the mean scores of both groups (i.e., retrospective $\&$ prospective) on the posttest of autonomy investigate the progress of autonomy in retrospective group in comparison with prospective group. The mean scores for the posttest of retrospective and prospective groups on the inventory were 69.52 and 66.19 , respectively. The Independent $t$-test for questions 1 to 11 of the inventory for the two groups is shown in table 8 below.

TABLE 8.

INDEPENDENT T-TEST FOR QUESTIONS 1 TO 11 OF THE INVENTORY FOR THE TWO GROUPS

\begin{tabular}{|c|c|c|c|c|c|c|c|c|}
\hline & \multicolumn{2}{|c|}{$\begin{array}{l}\text { Levene's Test for Equality of } \\
\text { Variances }\end{array}$} & \multicolumn{5}{|c|}{ t-test for Equality of Means } \\
\hline & & $\mathrm{F}$ & Sig. & $t$ & df & $\begin{array}{l}\text { Sig. (2- } \\
\text { tailed) }\end{array}$ & \begin{tabular}{|l} 
Mean \\
Difference
\end{tabular} & $\begin{array}{l}\text { Std. Error } \\
\text { Difference }\end{array}$ \\
\hline Inventory & Equal variances assumed & .469 & .498 & 1.189 & 40 & 242 & 3.33333 & 2.80411 \\
\hline Retro Pros & Equal variances not assumed & & & 1.189 & 39.989 & 242 & 3.33333 & 2.80411 \\
\hline
\end{tabular}

It can be seen that the probability of $\mathrm{t}(1.18)$ had the sig (.242) that is much higher than the significance level of .05 . As a result, no significant difference between the mean scores of the participating groups on their Autonomy Inventory could be recorded, although the retrospective group scored slightly higher than the prospective group. Consequently, our null hypothesis that "retrospective corrective feedback does not lead to more autonomy in EFL learners than prospective corrective feedback." is not rejected due to probability measure. The next part of the data analysis is concerned with questions 12 to 21 of the autonomy inventory which are descriptively analyzed.

Reliability Statistics of Questions 12-21 for "Retrospective" Group

The reliability statistics for questions 12-21 for "retrospective" group is presented in table 8.

TABLE 8.

RELIABILITY STATISTICS

\begin{tabular}{|l|l|}
\multicolumn{2}{c}{ RELIABILITY STATISTICS } \\
\hline Cronbach's Alpha & N of Items \\
\hline 741 & 10 \\
\hline
\end{tabular}

As it can be seen in table 8 above, the Cronbach's Alpha statistics for the questions 12-21 is .741 for the retrospective group.

\section{Reliability Statistics of Questions 12-21 for "Prospective" Group}

The next part of the data analysis is concerned with questions 12 to 21 of the autonomy inventory which are descriptively analyzed. The reliability statistics for questions 12-21 for prospective group is presented in table 9 below.

TABLE 9.

RELIABILITY STATISTICS

\begin{tabular}{|l|l|}
\hline Cronbach's Alpha & N of Items \\
\hline 709 & 10 \\
\hline
\end{tabular}

As it can be seen in table 19 above, the Cronbach's Alpha statistics for the questions 12-21 is .709 for the prospective group.

\section{DiscuSSION AND CONCLUSION}


There's no question that writing is a complex skill in nature, that's why it always absorbs so much attention as one of the four main language skills and needs much practice to be mastered (Rezapanah \& Hamidi, 2013). As argued by Abdolmanafi-Rokni, Hamidi and Gorgani (2014), any strategy or methodology which is capable of improving the learners' language proficiency should be put into practice. Corrective feedback is one such strategy which could improve learners' writing ability. Contrary to the numerous studies on the benefits of corrective feedback (e.g. Ellis, 2010; Ferris, 2010; Manchón, in press; Sheen, 2010), researchers in L2 writing SLA domains, have been primarily eager to the question if and how corrective feedback can enhance the learner's autonomy in writing process (Chandler, 2003).

To make any type of feedback an effective tool in the writing classroom, teachers have to adopt feedback methods that encourage students. There has to be a teacher who adopts resources, materials and methods to the learner`s need and even abandon all if needed. There are different perspectives in correcting the learner`s errors by the teacher, whether to correct or not, whether to correct at the spot or to delay the correction. In most of the classroom, teachers determine what students do and how they do. From the research, it was revealed that giving feedback at the beginning of the class made the teaching program more responsive to learner`s progress.

Regarding the first hypothesis, the result revealed that there actually is not a significant difference between pretest and posttest of students who work writing with retrospective corrective feedback. This finding is contrast with the study done by Kepner (1991), Truscott (2007), and Sheppard (1991). Shappard also noted that corrective feedback regressed learners over time.

As to the second research hypothesis the result revealed that there actually is a significant difference between pretest and posttest of students who work writing with retrospective corrective feedback. So it can be concluded that corrective feedback was helpful in developing learner`s writing ability. This finding is consistent with a large body of literature on the efficacy of written corrective feedback for helping L2 writers improve the accuracy of their writing. Ohta (2001), Ashwell (2000), Fathman and Whalley (1990). It is also in line with Panova and Lyster (2002), who claimed that corrective feedback enables learners to notice the gap between their inter-language forms and the target language forms, make further hypothesis and prevent errors from further production.

Regarding the third research question, the result revealed that there actually is not a significant difference between those students who work writing with retrospective corrective feedback and those students who work with prospective corrective feedback. Such a finding is not consistent with some studies. For example, Freedman (1987) holds that if learners fail in their writing performance, more feedback is required to help them make correct decisions on their writing process so that they can improve it as we can see, further feedback is not helpful in retrospective group to perform better in writing.

And finally, as to our fourth research hypothesis there was a slight difference between the mean scores of the two groups on the writing section on the surface. Although the researcher received different answers from different groups neither prospective error feedback group nor retrospective error feedback group, did not performed better in this study in order to improve learner autonomy. This finding is consistent with suggestions by researchers that prodding the learner to self correct is effective in prompting acquisition (Lyster, 2004). According to Hedge (2000), teachers are often advised to give the students the opportunities of self-correct and the teacher takes on some responsibility for correction but leaves it up to the student to make the actual correction.

Pedagogically speaking, the results of this study support the assumption that corrective feedback can positively influence on developing EFL learners and giving feedback is practical in writing ability. The results of this study also support similar research done by Ellis (2009). Ellis (2008) believed in theoretical reasons for expecting the focused approach to be more beneficial to accuracy development. In this study, the prospective corrective feedback focused on the frequent errors that the participants of retrospective group made, can play the role of focused corrective feedback and as the findings show the prospective corrective feedback had a positive role in developing learners` writing ability. This finding is in consistent with Schmidt (1994) and Ellis (2005) finding, who concluded that focused corrective feedback has greater potential to impact accuracy development. On the other hand, the retrospective corrective feedback plays the role of unfocused feedback, because the feedback provided by the teacher to the participants were not selective and it was based on all errors that the participants made.

As this research shows, in prospective corrective feedback, learners could benefit from indirect correction feedback. Whereas direct feedback consists of an indication of errors and the corresponding error linguistic form, indirect feedback only indicates that an error has been made. Instead of providing the target form, the teacher may leave the learner to correct his own errors. So we can assume the prospective corrective feedback as a kind of indirect corrective feedback in the classroom, because the teacher just informs participants of some errors before the writing and do not provide the correct form. It is then hoped that learners will take the advantages of indirect feedback since they have to be involved in a more characteristic forms of language processing when they are capable of self-editing their own writings (Ferris1995; Lalande1982), so improve much in the light of prospective and retrospective corrective feedback. 


\section{REFERENCES}

[1] Abdolmanafi-Rokni, S.J., Hamidi, H., \& Gorgani, T. (2014). Investigating the relationship between emotional intelligence and language achievement: A case of TEFL and Non-TEFL university students. International Journal of Language Learning and Applied Linguistics World, 5 (3), 117-127.

[2] Adams, R. (2003). L2 output, reformulation and noticing: Implications for IL development. Language Teaching Research, 7(3), 347-376.

[3] Arnaudet, M. L., \& Barret, M. E.(1981). Paragraph development: A guide for students of English as second language .Prentice Hall, Inc, Englewood cliffs

[4] Ashwell, T. (2000). Patterns of teacher response to student writing in multiple-draft composition classroom: Is content feedback followed by form feedback the best method? Journal of Second Language Writing, 9(3), 227-258.

[5] Benson, P. (2001). Teaching and researching autonomy in language learning. Harlow: Longman/Pearson Education.

[6] Bitchener, J., (2008). Evidence in support of written corrective feedback. Journal of Second Language Writing, 17(2), 102-118.

[7] Chandler, J. (2003). The efficacy of various kinds of error feedback for improvement in the accuracy and fluency of L2 student writing. Journal of Second Language Writing, 12(3), 267-296.

[8] Chaudron, C. (1988). Second language classrooms: Research on teaching and learning. Cambridge, UK: Cambridge University Press.

[9] Ellis, R. (2005). Principles of instructed language learning. System, 33(2), 209-224.

[10] Ellis, R. (2008). A typology of written corrective feedback types. ELT Journal, 63(2), 97-107.

[11] Ellis, R. (2009). Corrective feedback and teacher development. L2 Journal, 1(1), 3-18

[12] Ellis, R. (2010). A framework for investigating oral and written corrective feedback. Studies in Second Language Acquisition, $32(2), 335-349$

[13] Fathman, A., \& Whalley, E. (1990). Teacher response to student writing: Focus on form versus content .In B. Kroll (Ed.), Second Language Writing: Research Insights for the classroom (pp.178-190). Cambridge: Cambridge University Press.

[14] Ferris, D. R. (1995a). Can advanced ESL students be taught to correct their most serious and frequent errors? CATESOL Journal, 8, 41-62.

[15] Ferris, D. R. (1995b). Teaching ESL composition students to become independent self- editors. TESOL Journal, 4(4), 18-22.

[16] Ferris, D. (1999). The case of grammar correction in L2 writing classes: a response to Truscott (1996). Journal of Second Language Writing, 8(1), 1-11.

[17] Ferris, D. (2010). Second language writing research and written corrective feedback in SLA. Studies in Second Language Acquisition, 32(2), 181-201.

[18] Freedman, S. (1987). Response to student writing. Urbana: National Council of Teachers of English.

[19] Hedge, T. (2000). Teaching and learning in the language classroom. Oxford: Oxford University Press.

[20] Holec, H. (1981). Autonomy and foreign language learning. Oxford: Pergamon.

[21] Kepner, C. G. (1991). An Experiment in the relationship of types of written feedback to the development of second language writing skills. The Modern Language Journal,75 (3), 30.

[22] Lalande, J. F. (1982). Reducing composition errors: An experiment. The Modern Language Journal, 66(2), 140-149.

[23] Lyster, R. (2004). Different effects of prompts and recasts in form-focused instruction. Studies in Second Language Acquisition, 26(3), 399-432.

[24] Lyster, R., \& Mori, H. (2006). Interactional feedback and instructional counterbalance. Studies in Second Language Acquisition, 28, 269-300.

[25] Ohta, A. S. (2001). Second language acquisition processes in the classroom: Learning Japanese. Mahwah, NJ: Lawrence Erlbaum.

[26] Manchón, R. M. (in press). The language learning potential of writing in foreign language lessons from research. In M. Reichelt \& T. Cimasko (Eds.), Foreign language writing. Research insights. West Lafayette: Parlor Press.

[27] McGrath, I. (2002). Materials Evaluation and Design for Language Teaching._Edinbuurgh: Edinburgh University Press.

[28] Panova, I., \& Lyster, R. (2002). Patterns of corrective feedback and uptake in an adult EFL Classroom. TESOL Quarterly, $36,573-595$

[29] Rezapanah, F., \& Hamidi, H. (2013). Investigating the effects of word games on Iranian EFL learners' application of the words in writing paragraph essays. International Journal of Applied Linguistics \& English Literature, 2 (1), 35-43.

[30] Schmidt, R. (1994). Deconstructing consciousness in search of useful definitions for applied linguistics. AILA Review, 11, 1126.

[31] Sheen, Y. (2010a). The role of oral and written corrective feedback in SLA. Studies in Second Language Acquisition, 32(2), 169-179.

[32] Sheen, Y. (2010b). Differential effects of oral and written corrective feedback in the ESL classroom. Studies in Second Language Acquisition, 32(2), 201-234.

[33] Swain, M. (1995). Three functions of output in second language learning. Principle and Practice of applied linguistics: studies in honor of H. G. Widdowson. G. Cook and B. Seidhoffer. Oxford, Oxford University Press: 125-144.

[34] Truscott, J. (1996). The case against grammar correction in L2 writing classes. Language Learning, 46(2), 327-369.

[35] Truscott, J. (1999). The case for "The case against grammar correction in L2 writing classes": A Response to Ferris. Journal of Second Language Writing, 8(2), 111-122.

[36] Truscott, J. (2007). The effect of error correction on learners' ability to write accurately. Journal of Second Language Writing, $16(4), 255-272$.

[37] Wenden, A. (1998). Learner strategies for learner autonomy. Great Britain: Prentice Hall. 


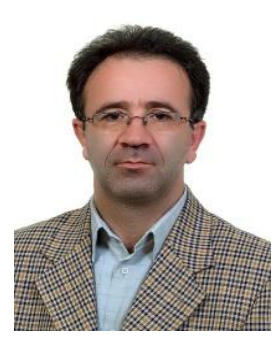

Gholam-Reza Abbasian was born in Ahar, I.R. of Iran in 1964, holds his PhD in applied linguistics from the Science \& Research Campus of IAU of Iran in 2005. Abbasian, as an assistant professor of TEFL at Imam Ali University \& IAU, has presented at (inter) national conferences, is the author \& translator of about 15 books, publisher of scholarly articles and offers psycholinguistics, language testing, \& syllabus design courses at MA level. Dr. Abbasian is the internal manager of JOMM, reviewer of Sage, FLA and GJER journals and a member of editorial board of JSSIR. He has received awards as top scholar and been nominated as the most successful teacher for six years.

Poopak Bahmani is an M.A. graduate student in TEFL from South Tehran Branch of Islamic Azad University. She has recently finished her M.A. studies at the above mentioned university. She has been teaching English for about 5 years in qualified English institutes in Tehran and Damavand, Iran. 